\title{
The perception of nurses regarding educational practices for children with diabetes in hospital care ${ }^{a}$
}

\author{
Percepções de enfermeiras acerca da prática educativa \\ no cuidado hospitalar a crianças com diabetes
}

Percepciones de enfermeras acerca de la práctica educativa

en la atención hospitalaria a niños con diabetes

\author{
Viviane Peixoto dos Santos Pennafort ${ }^{\mathrm{b}}$ \\ Amanda Newle Sousa Silvac \\ Maria Veraci Oliveira Queiroz ${ }^{\mathrm{d}}$
}

\begin{abstract}
The aim of this study was to describe the perception of nurses regarding educational practices conducted with children with diabetes in a hospital unit. It is a descriptive qualitative study, conducted in an inpatient unit of a public hospital in Fortaleza, state of Ceará, Brazil, between January and February of 2013, with six nurses. Data were collected by means of semi-structured interviews and submitted to content analysis, from which two categories emerged: role of nurses and staff in caring for the child with diabetes: the necessary intersection; and health education directed at the child with diabetes and family members in the hospital context. Nursing professionals acknowledged educational activities as part of an interdisciplinary care strategy which must occur since the moment the child is admitted. However, they displayed a reductionist view, centered on insulin therapy and changes of habit, which indicates the need for more creative approaches, capable of enhancing learning aspects and minimizing the gaps which prevent the disease from being managed appropriately.
\end{abstract}

Descriptors: Child, Hospitalized. Diabetes Mellitus, Type 1. Health education. Nursing care. Pediatric nursing.

\section{RESUMO}

Objetivou-se descrever a percepções de enfermeiras acerca da prática educativa junto às crianças com diabetes em unidade hospitalar. Estudo descritivo, de abordagem qualitativa, realizado em unidade de internação de hospital público, em Fortaleza, CE, de janeiro a fevereiro de 2013, com seis enfermeiras. Na coleta das informações, utilizaram-se entrevistas semiestruturadas submetidas à análise de conteúdo, e emergiram duas categorias: atuação da enfermeira e da equipe no cuidado à criança com diabetes: a interseção necessária e educação em saúde voltada à criança diabética e sua família no contexto hospitalar. As enfermeiras reconheceram a atividade educativa como estratégia de cuidado interdisciplinar, que deve acontecer desde a admissão da criança no hospital. Contudo, apresentaram percepção reducionista, centrada na insulinoterapia e mudança de hábitos, o que demonstra a necessidade de abordagens mais criativas, capazes de potencializar os aspectos de aprendizagem e minimizar as lacunas que dificultam o adequado manejo da doença. Descritores: Criança hospitalizada. Diabetes Mellitus tipo 1. Educação em saúde. Cuidados de enfermagem. Enfermagem pediátrica.

\section{RESUMEN}

El objetivo fue describir las percepciones de enfermeras acerca de la práctica educativa en niños diabéticos en unidad hospitalaria. Estudio descriptivo, cualitativo, llevado a cabo en unidad de hospitalización de hospital público de Fortaleza/CE, Brasil, de enero a febrero de 2013, con seis enfermeras. En la recopilación de datos, se utilizaron entrevistas semiestructuradas sometidas a análisis de contenido, emergiendo dos categorías: actuación de la enfermera y del equipo al niño diabético: la intersección necesaria y educación en salud al niño diabético en contexto hospitalario. Las enfermeras reconocieron la actividad educativa como estrategia de atención interdisciplinaria que debe ocurrir desde el ingreso del niño al hospital. Sin embargo, se presentaron percepciones reduccionistas, centradas en la terapia de insulina y en el cambio de hábitos, lo que demuestra la necesidad de adoptar enfoques más creativos, capaces de mejorar los aspectos de aprendizaje y minimizar las brechas que impiden la correcta gestión de la enfermedad.

Descriptores: Niño hospitalizado. Diabetes Mellitus tipo 1. Educación en salud. Atención de enfermería. Enfermería pediátrica.
D0l: http://dx.doi.org/10.1590/19831447.2014.03.43313

a Extract from the research project "Diabetes infantojuvenil e tecnologia educativa-terapeutica: subsídios para o cuidado clínico de enfermagem", funded by Chamada Universal - MCTI/CNPq No 14/2012.

b Nurse. Doctoral student in the Health and Nursing Clinical Care Graduate Program, Ceará State University (PPCCLIS/UECE). Member of the Child and Adolescent Health Care Research and Study Group, Nursing - GEPCCA. CAPES scholar. Fortaleza, CE, Brazil.

' Undergraduate student in the $8^{\text {th }}$ semester of the UECE Nursing Program. Member of GEPCCA. Scientific initiation scholarship from FUnCAP. Fortaleza, CE, Brazil. ${ }^{d}$ Nurse. Ph.D. in Nursing. Faculty member of PPCCLIS/ UECE. Coordinator of GEPCCA. Fortaleza, CE, Brazil. 


\section{口INTRODUCTION}

Type 1 Diabetes Mellitus (Type 1 DM) is a chronic, autoimmune and multifactorial disease which can affect different age groups. It is most commonly diagnosed in children, adolescents and young adults. Medical care and health education for self-management are necessary in order to prevent acute complications and reduce the risk of chronic macro- and microvascular complications. ${ }^{(1)}$

We bring attention to the fact that there is a Diabetes Mellitus (DM) epidemic underway. By 2030, 300 million people are projected to be diagnosed with DM, people who depend on an onerous treatment from the socio-economic standpoint. Approximately two-thirds of individuals with DM are young and live in developing countries. In this context, the incidence of Type 1 DM has been increasing significantly among the population of children younger than five years, with great geographic variation. The rate per 100 thousand individuals under fifteen years is 38.4 in Finland; 7.6 in Brazil; and 0.5 in Korea ${ }^{(2)}$.

The changes imposed on the lives of these children are especially uncomfortable and continuous, for treatment consists of dietary restrictions, multiple insulin injections and necessary regular physical activity. This also includes the fear of possible complications and discomfort caused by hyper- and hypoglycemic symptoms. In order for the treatment to have a positive impact on the child's personal and family lives, care must consist not only of technical aspects, but also consider their physical, emotional and social needs $s^{(3)}$.

Suffering can be exacerbated when the child is hospitalized, generating uncertainty and maternal overload. Thus, we emphasize the essential role of health professionals alongside the mother-child duo, providing comprehensive, quality and more humane care. They must take them in the best way possible, establishing an ethical relationship and therapeutic bonds. ${ }^{(4)}$

In light of this reality, educational activities represent strategies that foster support, learning, independence and motivation for self care management, through dialogic and emancipatory actions, different from traditional models..$^{(5)}$

However, upon consulting national and international literature, we observed a scarcity of studies related to educational activities for children with diabetes. A systematic bibliographic search on the Scientific Electronic Library Online (SciELO) and the Web of Science databases, using "type 1 diabetes" and "health education" as descriptors, between 2006 and 2012, resulted in 26 articles. Of these, only six addressed educational practices, indicating that research in this field is still incipient.

In order to attain more effective communication, health educators must be familiar with the reality, worldview and expectations of each subject. Thus, priority should be given not only to therapeutic demands, but also to the needs of each child. Professionals must base their actions on the pre-existing knowledge regarding the children, for when their experience is disregarded, there are a series of possible consequences. These include: treatment nonadherence, distrust of the therapeutic relationship, deficient self-care, adoption of harmful beliefs and habits regarding health, a distancing from the multiprofessional team, cultivating the notion that only others are responsible for their care, among others. ${ }^{(5)}$

In nursing care, the potential of health education must be recognized as a comprehensive approach that includes risk prevention and health promotion through actions that encourage the participation of the interested population and allows for an approximation with the life context of these individuals. In this sense, children and their families are capable of learning and sharing knowledge regarding health and quality of life. ${ }^{(6)}$

Health education began to be investigated and reflected on due to the recognition that it is common for nurses to distance themselves from this activity, or do not perform it at all. Health education should aim at considering the needs and learning conditions of children with diabetes, in such a way that children and family members can understand, make decisions and take action regarding their health condition, thus complying with the therapeutic plan shared by the team. Therefore, we based our study on the following question: how do nurses perceive educational practices for children with diabetes in hospital care?

Our intention is to contribute with reflections which can lead to the development of educational activities with children with diabetes in care environments, involving them actively in their learning experience so that, together with their families, they can incorporate practical knowledge mediated by scientific knowledge. To answer the question above, our objective was to describe the perception of nurses regarding educational practices with children with diabetes in a hospital unit.

\section{METHODOLOGY}

A descriptive qualitative study was conducted in a Pediatric Inpatient Unit of a tertiary public hospital in Fortaleza, state of Ceará, Brazil, between January and February of 
2013. This unit has 36 beds and deals mainly with the hospitalization of clinical patients for diagnostic investigation and treatment purposes. Since it is a teaching hospital with residency programs in this specialty, clinical investigation is also of interest.

The unit was composed of a multiprofessional team with ten aid nurses. Of these, six participated in the study, chosen intentionally during meetings. Inclusion criteria were as follows: caring for children diagnosed with Diabetes Mellitus and having at least six years of experience in the field. Nurses who worked only night shifts were excluded. Interviews were canceled when the information obtained was repetitive or redundant.

Data were collected using a semi-structured interview with the following guiding questions: 'how do you perceive educational practices for children with diabetes and their families?'; and 'how do you develop this practice in the context of hospitalization?'. The interviews were recorded with the participant's permission and authorization, as stated in the free and informed consent form.

Data were analyzed using content analysis, in three operational phases of pre-analysis; material exploration; result analysis, inference and interpretation ${ }^{(7)}$. Pre-analysis consisted of organizing the material and preparing it by "editing" the transcribed interviews. Units of analysis were highlighted during horizontal and vertical readings, using colored pencils to underline similar units with the same color.

The following phase consisted of grouping similar units, i.e., categorization: inventory (common elements are isolated) and classification (elements are separated and the message is given a certain organization). In this phase, two categories emerged: performance of nurses and staff when caring for the child with diabetes: the necessary intersection, and health education directed at the child with diabetes and family members in the hospital context. Lastly, the results were analyzed, and then discussed based on the literature.

Our research complied with the requirements of resolution 466/2012 $2^{(8)}$, and was associated with the "Type I diabetes and educational-therapeutic technology: information for clinical nursing care" project, approved by the Research Ethics Committee of Ceará State University (UECE), as stated in resolution no. 181.489. The project received the support of the Brazilian National Council for Scientific and Technological Research (CNPq). In order to guarantee the anonymity of the participants, they were identified by the letter "I," followed by the number of the order in which they were interviewed.

\section{RESULTS AND DISCUSSION}

All participants were female; and most were young, with a mean age of 25 years. The majority had recently graduated and held no specialization in Pediatrics. They had been hired through a nursing cooperative, a fact which contributed to the sector's frequent turnover and which hindered approximation and the acquisition of skills for caring for children with diabetes.

\section{The role of nurses and the staff in caring for the child with diabetes: a necessary intersection}

This category emphasized the role of nurses in health education from the moment the child is admitted to the Pediatrics unit. It also indicated the need for an interdisciplinary team in order to provide comprehensive care to the hospitalized child with diabetes.

In the report of 12 , we observe a concern for investigating the child and family's previous knowledge about the disease and blood-glucose control.

The child arrives at the ward and we try to find out if he or she has already received orientation, because most of them first discover they are diabetic when they are admitted. Providing them with orientation from the beginning will help the patient further on to have control, to be educated and disciplined. We try to find out if they have already received orientation, for there is a ward in the outpatient clinic that deals solely with health education for diabetic children. [12]

International experiences have demonstrated the importance of educating parents and the recently-diagnosed child with Type 1 DM from the moment they are admitted until discharge. In Sweden, when a child is diagnosed with Type $1 \mathrm{DM}$, both the child and his/her family remain in the hospital for approximately two weeks, receiving guidance from a nurse and a pediatrician specialized in diabetes, according to each family's specificities. This program favors the acquisition of the knowledge and skills necessary for conducting blood-glucose control at home. ${ }^{(9)}$

The nurses also touched on the importance of providing orientation on how to control the disease. They emphasized that although there was a nurse responsible for health education in the outpatient clinic, other nurses who work alongside children and their families in the ward also carry out educational actions.

I think that the role of nurses, besides providing care in unit sectors, is essential for educating not only the child, but 
also their relatives, showing the complete importance of the insulin and diet in the child's life cycle. It is an important exchange, it makes our lives as nurses richer, makes us grow as professionals, as well as personally, due to the worth given to their health (the children's); nursing is really about the art of caring. [13]

All nurses here have the knowledge, but not everyone has the availability to talk and explain, not only because of how hurried the shifts are, but also because that's not the nurse's profile, most nurses here sit down with the mothers [...] explain the disease, how to care for it, encourage the mother and the child to learn how to perform blood glucose self-tests, but since our shifts are so busy, it's hard, the time we have with them is short and we cannot dedicate ourselves only to them, for there are all the others as well. [11]

Despite these remarks, nurses recognize the need for a multiprofessional team when caring for children with type 1 diabetes as a strategy for providing support and favoring treatment adherence.

A multiprofessional team is necessary, not only with nurses, for psychologists and nutritionists have important roles in treatment adherence. [14]

There is no psychological counseling, for the child or the family. [11]

These excerpts represent a subtle call for integrated care among healthcare team members, so that by the joining of knowledge, treatment can be effective and quality care provided.

This approach was also mentioned in another study, which stated that health professionals cannot restrict themselves to technical care without considering the emotional and psychological aspects of the informal caretakers, for they are directly related to the treatment adherence of the child with Type $1 \mathrm{DM}^{(10)}$. In this sense, the family's experience must be valued, so that it can be integrated to and negotiated with professional knowledge, thus providing the child with better care.

\section{Health education directed at the child with diabetes and family members in the hospital context}

In this category, participants reported educational practices that effectively took place, which consisted main- ly of orientation. Some made reference to the objective: to facilitate the understanding and learning of children and family members regarding insulin therapy, diet, hygiene, physical activity and accident prevention.

Educational practice has focused primarily on diet, the correct use of insulin, handling the equipment, the glucose test strip ... teaching the chaperone so that they can do it properly at home. It is important for the child to have a healthy diet in order to have better glucose control (...) the correct way to wash hands. [13]

It is a matter of providing orientation on personal hygiene, preventing accidents, preventing cuts (...) application site, hygiene; we always instruct them to wash their hands before capillary blood glucose, so that their little fingers are clean, because it is an entryway for infection, and we also provide orientation regarding their diet. [11]

In caring for these children, nurses tended to emphasize glucose control, which is certainly a priority; however, the child's psychosocial dimensions cannot be neglected, such as playing and socializing in collective environments and at school.

When considering this gap, our content analysis did not identify a more directed plan or action based on a theoretical framework which instigates the autonomy of the child with diabetes, preparing him/her to take responsibility for self-care, under their caregiver's supervision, and manage and promote their health.

It is important to emphasize that the goal of the caregiver in educational activities should not be so much providing care, but inciting in the child the desire for self-care. This implies in a desire for continuous transformation, and evaluating what can be better done and/or said in each particular circumstance. ${ }^{(11)}$

To optimize health education for children, the nurses mentioned the joint action of a qualified multidisciplinary team and the family. Such action makes it easier to overcome challenges and foster the development of self-care.

We [professionals] are responsible for passing on this information in the child's daily life in the hospital [...] there has to be much educational work, both by the professional teams and by the families, guiding the child from a young age, so that they can get used to self-care. We need to develop such educational work with the child, patiently, carry out actions aimed at the child. [14] 
Thus, nurses emphasized the relevance of educational practices in the hospital setting, considering it a strategy for the care of the child. They highlighted the fundamental importance of educating family members so that they can aid the child in carrying out their treatment, and thus avoid hospitalization and maintain a healthy lifestyle.

This [educational practice] is important so that the child is not hospitalized again, so that they know that when diabetes is treated properly, with the due precautions, the child can lead a normal life like any other child. [13]

In this perspective, involving the family in the care process is fundamental for treatment compliance among school-aged children. This initiative very often leads to the family changing their behavior and life style..(12) Thus, the nursing professional must insert and implement educational activities in these settings, fostering the development of the child's health management skills.(5)

Encouraging the child's autonomy for applying insulin was also mentioned as an important tool that fosters responsibility for treatment and health improvement. This is especially applicable when the family is not involved in the treatment.

We want the child to leave here well and continue to be well in his/her every day life, we want them to be able to go to school well, and if they need insulin injections, that they take their equipment with them or apply the injection before going to school. It's common to see mothers who do not take an interest in their child's disease, so they leave all the responsibility up to child and just don't care. [13]

Every time we apply insulin, we provide full orientation, we don't like to do it, we want the child to do it so that they can learn and be more autonomous. [15]

In this context, the time spent in the hospital, sharing the child's care with the healthcare team can be an opportunity for the relatives to reflect on themselves as a family. Based on this experience, they can build new ways to care for their child and provide more instrumental and effective care. ${ }^{(13)}$

Further evidence demonstrates that the child values the support given by their family, who are directly involved in fostering self-care. Other external network members are also of value. Attention should also be given to the school setting, each child's specific experience, and health education..$^{(14)}$
Some aspects were listed as significant for diabetes management. For instance, the nurses pointed out that the mother's level of education can influence the child's care.

(...) it is noticeable when a mother has more education and it is easier for her to understand the explanations given by the nurses regarding her child's care, and this leads to better treatment adherence. [14]

The mother's level of education is certainly a factor that can lead to providing the child with better care. However, when education levels are low, nurses can use other strategies appropriate for families who have no formal education, but who possess other experiences that are of help when learning about the essential components of their child's care.

Furthermore, type 1 diabetes in children presents some specific situations which must be carefully evaluated, for blood-glucose control is also affected by the family's socio-economic condition. Its control depends on the availability of materials for treatment, adequate diet, quality of living conditions and access to essential services, such as sanitation and healthcare. ${ }^{(15)}$

Although attention is given to health education in the studied institution, nurses made reference to aspects which made this practice difficult, such as the lack of educational material.

I believe that educational practices could improve, but due to the hospital setting, it is more difficult than at a health center. When we can't get something, we send patients to the outpatient clinic to nurse $X$, for they have more resources for providing orientation, such as dolls. We focus more on how the child is doing it, how insulin is applied, and based on that, we teach, make corrections and answer questions. [15]

There is a lack of educational material for us to hand out, since they don't always remember everything we say, it would be important to have access to this material so that they can read it when they're not in any activity, for the family, especially for visitors. [11]

When health professionals establish close relationships with the children and access their preferences, they can identify different forms of care and health education. The use of creative and age-appropriate resources, modern technologies, and educational books and pamphlets tend to increase verbal expression, favoring 
the child's involvement and understanding of diabetes care. Furthermore, using appropriate pedagogical resources which the child considers significant can promote confidence, both for the child and the health professional, with respect to the veracity of the information being taught. ${ }^{(5)}$

In addition, theoretical concepts regarding child development, health promotion, family nursing and specific aspects of health education for children with diabetes need to be accessed and incorporated into the care plan, elaborated and implemented by nurses.

\section{GINAL CONSIDERATIONS}

The objective of this study was to describe the perception of nurses regarding educational practices for children with diabetes in a hospital unit. Due to the impact of diabetes mellitus in the child and family's lives, educational strategies must be valued and implemented. In so doing, it is possible to increase knowledge about the disease and its treatment, intensify autonomy, and facilitate self-care. This requires a joint effort of the family, professionals and the child's participation.

Despite the little experience of some of the nurses, they recognized their responsibility in carrying out educational activities; they strive to be involved from the moment the child is admitted, learning previous information and "exchanging experiences" with the children and their families. However, they displayed reductionist views, centered on insulin therapy, blood-glucose testing and change of habits and behaviors. We were not able to identify more effective actions for involving and motivating children to care for the disease, so that they can take responsibility for its management with the help of their families.

In the nurses'implicit discourse, it was clear that these professionals spend more time with the children in the hospital setting, providing care and developing "educational" activities. The multidisciplinary team was emphasized as being necessary during hospitalization. Nutritionists would care for the child's dietary restrictions and adaptations, while psychologists would be essential for supporting children and families in the illness and treatment process.

Undoubtedly, in order to adequately manage type I diabetes in children, education and ongoing interdisciplinary care are fundamental. It is necessary to encourage the active participation of the child and family members, helping them understand the fundamental aspects of treating and controlling the disease by shar- ing responsibilities among the healthcare team, child and family. Ultimately, these actions allow for better quality of life.

We highlight that the study presents some limitations, for it analyzed only the experience of nurses with educational practices. Therefore, further studies are needed in order to encompass the universe of care for the child and family, thus deepening discussions on the issue.

When caring for children with diabetes, health professionals in general, and nurses in specific, must identify priorities and efficient and creative strategies which enhance learning aspects and reduce the gaps which make it difficult to manage the disease appropriately.

\section{口EFERENCES}

1. Gomes MB, Cobas R. Diabetes mellitus. In: Grossi SAA, Pascali PM, organizadoras. Cuidados de enfermagem em diabetes mellitus: manual de enfermagem. São Paulo: Departamento de Enfermagem da Sociedade Brasileira de Diabetes; 2009. p. 6-17.

2. Sociedade Brasileira de Diabetes (SBD). Diretrizes da Sociedade Brasileira de Diabetes: 2013-2014. São Paulo: AC Farmacêutica; 2014.

3. Almino MAFB, Queiroz MVO, Jorge MSB. Diabetes mellitus na adolescência: eXperiências e sentimentos dos adolescentes e das mães com a doença. Rev Esc Enferm USP. 2009;43(4):760-7.

4. Figueiredo SV, Gomes ILV, Pennafort VPS, Monteiro ARM, Figueiredo JV. Sentimentos de mães atribuídos à hospitalização de um filho. Cogitare Enferm. 2013;18(3):552-7.

5. Sparapani VC, Nascimento LC. Recursos pedagógicos para crianças com diabetes mellitus tipo 1 e seus amigos: a influência dessa interação no manejo da doença. Sau Transf Soc. 2010; 1(1):113-9.

6. Corrêa CRA, Navarro JP. Educação em saúde a crianças: a ludicidade como estratégia. In: Mattos M, Veronesi CL, Silva Júnior AJ. Enfermagem na educação em saúde. Curitiba: Prismas; 2013. 255 p.

7. Bardin L. Análise de conteúdo. Trad. Luís Antero Reto e Augusto Pinheiro. Lisboa: Edições 70; 2010.

8. Ministério da Saúde (BR), Conselho Nacional de Saúde. Resolução No 466 de 12 de dezembro de 2012. Dispõe sobre as diretrizes e normas regulamentadoras de pesquisas envolvendo seres humanos. Diário Oficial da União [da] República Federativa do Brasil. 2013 jun 13;150(112 Seção 1): 59-62.

9. Jönsson L, Hallström I, Lundqvist A. A multi-disciplinary education process related to the discharging of children from hospital when the child has been diagnosed with type 1 diabetes: a qualitative study. BMC Pediatr. 2010; 10:36.

10. Sales CA, Tironi NM, Artibale D, Ferreira E, Silva MAP, Violin MR, et al. Cuidar de uma criança com diabetes mellitus tipo 1: concepções dos cuidadores informais. Rev Eletr Enf [Internet]. 2009 [citado 2012 out 20];11(3):563-72. Disponível em: http://www.fen.ufg.br/fen_revista/ v11/n3/pdf/v11n3a13.pdf.

11. Machado LD, Lavrador MCC. For a clinic to expand life. Interface Comunic Saude Educ. 2009;13(supl.1):515-21. 
12. Rubin 0, Azzolin K, Muller S. Adesão ao tratamento de diabetes mellitus tipo 1 atendidos em um programa especializado em Porto Alegre. Medicina. 2011;44(4):367-76.

13. Gomes GC, Oliveira PK. Vivências da família no hospital durante a internação da criança. Rev Gaúcha Enferm. 2012;33(4):165-71.
14. Nascimento LC, Amaral MJ, Sparapani VC, Fonseca LMM, Nunes MDR, Dupas G. Diabetes mellitus tipo 1: evidências da literatura para seu manejo adequado, na perspectiva de crianças. Rev Esc Enferm USP. 2011;45(3):764-9.

15. Martins EMCS, Ataíde MBC, Silva DMA, Frota MA. Vivências de mães no cuidado à criança diabética tipo 1. Rev Rene. 2013;14(1):42-9.

\section{Author's address:}

Viviane Peixoto dos Santos Pennafort

Rua dos Coelhos, 135, Maraponga

60710-705, Fortaleza, CE

E-mail: vivipspf@yahoo.com.br
Received: 30.10.2013

Approved: 05.06.2014 